Acta vet. scand. $1974,15,206-218$.

From the Department of Pathology, Royal Veterinary College,

Stockholm, Sweden.

\title{
SENILE CARDIAC AMYLOIDOSIS \\ IN THE DOG
}

By

Lennart Jönsson

JONSSON, LENNART: Senile cardiac anyloidosis in the dog. Acta vet. scand. 1974, 15, 206-218. - Thirty-two cases of senile cardiac amyloidosis from a routine necropsy material of 594 dogs were studied. The age of the affected dogs ranged from 10 to 16 years. Amyloid was observed in the intramural arteries and arterioles, predominantly in the ventricular myocardium. The vessels were often obturated with amyloid, and myocardial necroses and fibroses were common consequences of the vascular lesions. In three cases amyloid deposits were also observed in the main subepicardial coronary arteries. In contrast to man, only slight interstitial amyloid degeneration was found in four of the dogs observed. Amyloid in the mitral valves, tricuspid valves and aortic cusps was observed in six, two and three cases respectively. It was concluded that the distribution of senile cardiac amyloidosis in the heart of the dog differs considerably from that in man.

a m y loidosis; heart; dog.

The dog is used a great deal as an experimental animal in comparative cardiovascular research. In view of this it is important to know which pathological changes spontaneously occur in the myocardium and the coronary arteries of this animal.

Cardiac amyloidosis is well known in man and is interpreted as a senile phenomenon. The literature on cardiac amyloidosis in the dog seems to be sparse. Coronary arterial amyloidosis of a dog was first reported by Hjärre \& Nordlund (1942). Further reports, which comprise a relatively small amount of necropsy material, did not appear until the 1960'es (Dahme \& Reif 1964; Schanz 1965; Trautwein 1965 a, b; Schwartz 1970; Jakob 1970). Several investigators have observed lesions interpreted as vascular hyalinosis in the intramural coronary arteries and arterioles. It is likely that some cases of vascular amyloidosis were described 
as hyalinosis in earlier literature because of the morphologic similarity.

It is interesting to compare the distribution of this type of amyloid in dog and man. It does not seem to be the same in the two species. In this study, routine necropsy material regarding the distribution of primary amyloidosis in the canine heart is investigated. Some comparative aspects of cardiac amyloidosis in man are presented.

\section{MATERIAL AND METHODS}

In the present investigation 594 dogs were randomly selected from routine necropsies. All dogs underwent complete necropsy. The hearts were weighed and opened in a routine manner. They were carefully examined macroscopically with special attention to changes in the extramural coronary arteries, in the atrioventricular, aortic and pulmonary valves and the myocardium.

Samples for histological examination were taken from the papillary muscles of the left ventricle, the lower and the upper halves of the interventricular septum and randomly from the right ventricular wall and the atria. The sites sectioned always included the atrioventricular valves and semilunar cusps. The samples were fixed in $10 \%$ neutral formalin. Where amyloid was demonstrated, further blocks were taken from each chamber, atrium, and septum in onder to compare the distribution of the deposits. Blocks from other organs were also examined for amyloid.

Paraffin-embedded sections were stained with haematoxylineosin, Verhoeff's elastic stain, PAS, Masson's trichrome and Goldner's modification of that stain. The presence of amyloid was demonstrated by the following methods: Alkaline Congo red (Puchtler et al. 1962) combined with examination in polarized light, thioflavine $T$ for fluorescence (Vassar \& Culling 1959) and metachromasia with crystal and methyl violet. The degree of cardiac amyloid was assessed as slight, moderate, or severe on the microscopic appearance.

\section{Incidence}

\section{RESULTS}

Senile cardiac amyloidosis was found in 32 cases. Ages ranged from 10 to 16 years; the average age was 13 years. Percentage incidence for all the cases examined was $16.5 \%$ in animals over 
10 years of age. In the age groups $10-11$ and $12-13$ the percentage incidence was 7.5 and 13.8 respectively. In the over-14 group there were 35 cases, of which $16(45.7 \%)$ showed cardiac amyloidosis.

\section{Macroscopical findings}

Cardiac amyloidosis was easily overlooked at necropsy, although all the hearts with this lesion showed macroscopical alterations. Multiple small foci of fibrosis were usually observed in the left ventricular wall and especially in the papillary muscles. The only diagnostic feature on macroscopic examination was the presence of minute greyish or translucent foci within the ventricular myocardium. At histological examination these foci were found to be intramural arteries with heavy deposits of amyloid. Slight and moderate amyloid deposits in the vessels were not seen macroscopically.

Valvular amyloidosis was demonstrated in six dogs. Large nodular thickenings (up to $5 \mathrm{~mm}$ in thickness) were observed in the free edge of the mitral valves. In severe cases the thickenings coalesced into irregular plaque-like deformities. Similar lesions were seen in the tricuspid valves in two cases. The aortic cusps were affected in three cases. In severe amyloidosis of the mitral valves the lesions extended to involve the proximal portions of the cordae terdineae.

\section{Microscopic appearance}

Cardiac amyloidosis was observed in the coronary arteries and arterioles of 32 animals. The amyloid deposits were primarily observed in the middle-sized and small intramural branches of the coronary arteries. The lesions began in the intima or in the media (Fig. 1). In some cases the deposits started as a massive circumscribed focus which gradually enlarged, extending into all layers of the vessel and progressively occluding its lumen (Figs. 2 and 3 ). The arteries which were almost completely obstructed by amyloid deposits had several clefts and channels, some of which were lined with endothelial cells. Necrosis and cicatrization of the cardiac muscle were typical consequences of this vascular lesion (Fig. 4). In three cases slight and moderate deposits were observed in the intimal and medial layers of the main coronary arteries. Accumulations of amyloid in these ves- 


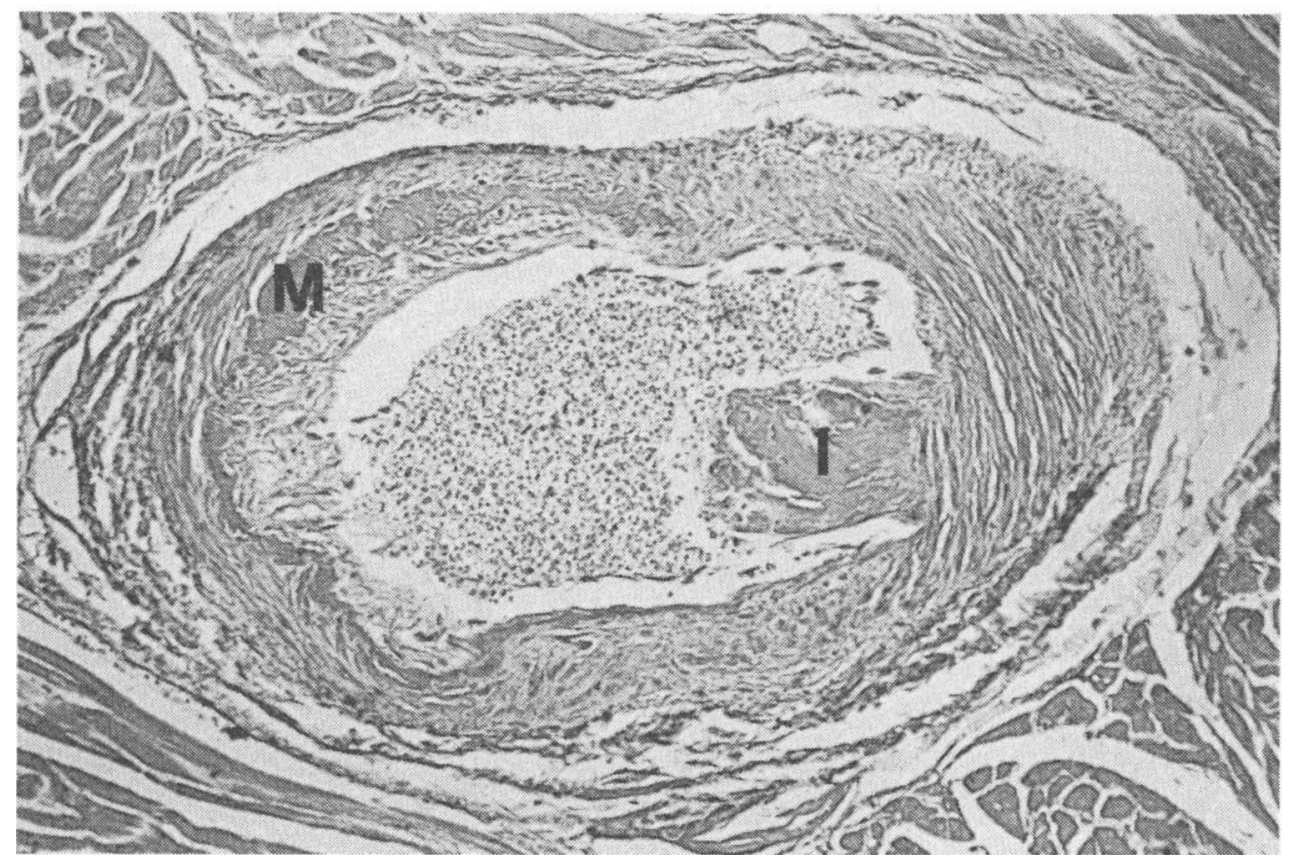

Figur e 1. Intramural coronary artery with slight amyloid deposits in the intima (I) and media (M). Alkaline Congo red. $\times 140$.

sels never became sufficiently large to cause any noticable enchroachment on the lumen.

Interstitial amyloid degeneration of the heart muscle was only observed in four cases. It was slight and variable in distribution. When present, it appeared as fine strip-like amyloid deposits surrounding the heart muscle fibers in the left ventricle. Interstitial cardiac amyloid degeneration without arterial amyloidosis was never observed.

Amyloid was observed microscopically in the mitral valves of six cases and in the tricuspid valves and the aortic cusps of two and three cases respectively. The valvular lesions appeared at first along the line of contact with the opposing valve. In cases of severe affection, the amyloid deposits were not only related to the line of closure of the valve but appeared as diffuse atrial thickening in the proximal portion of the valves (Fig. 5). The normally well-defined elastic lamina in the deepest part of the atrialis was frequently fragmented under these amyloid thicken- 


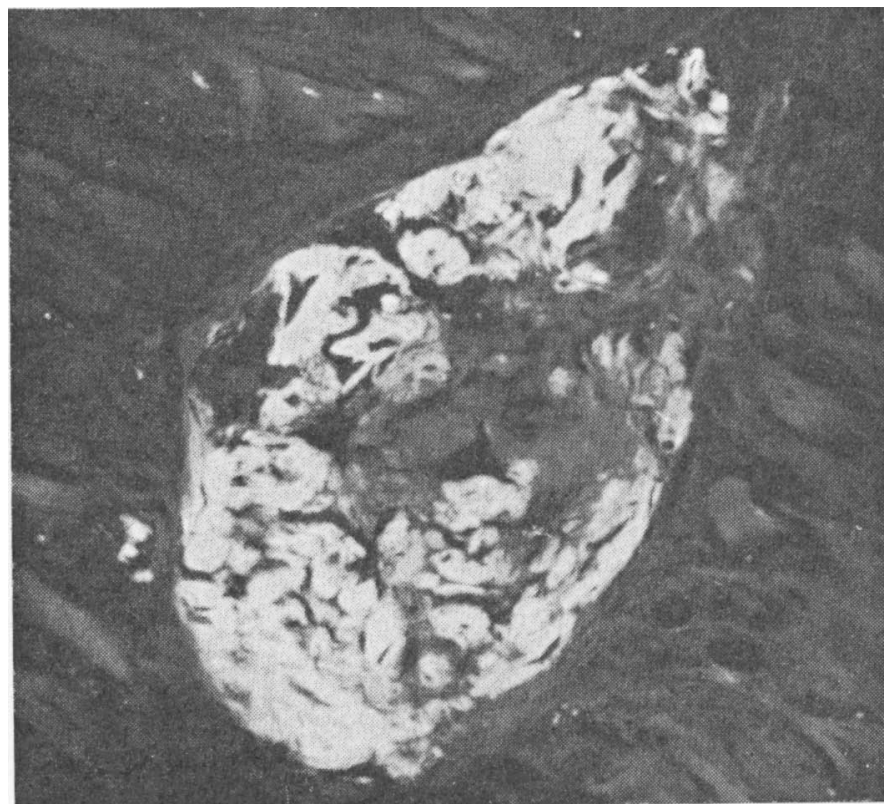

Figure 2. Arterial amyloid brightly fluorescent in u.v.-light. Thioflavine $T$ fluorescence. $\times 140$.

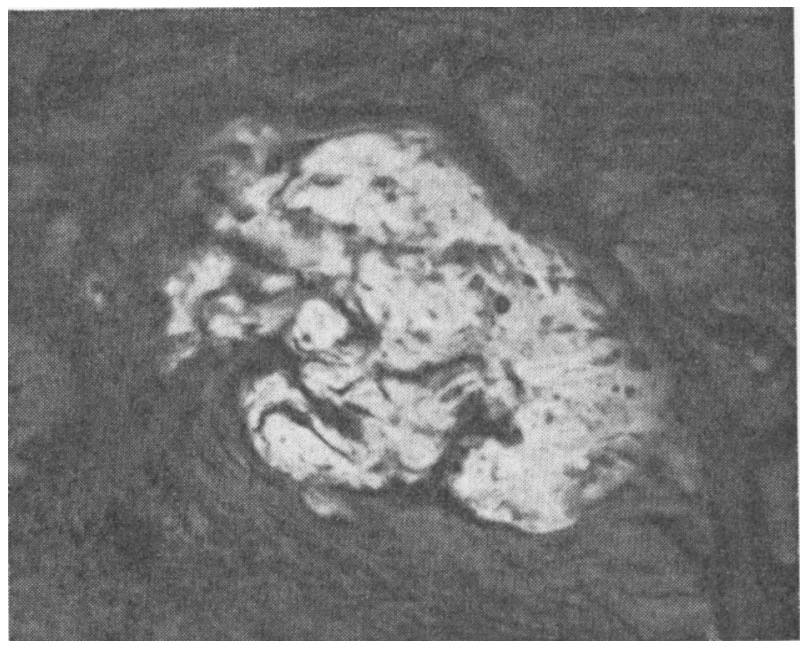

F i gure 3. Intramural arteriole with heavy deposits of amyloid. Thioflavine $\mathrm{T}$ fluorescence. $\times \mathbf{2 1 0}$. 


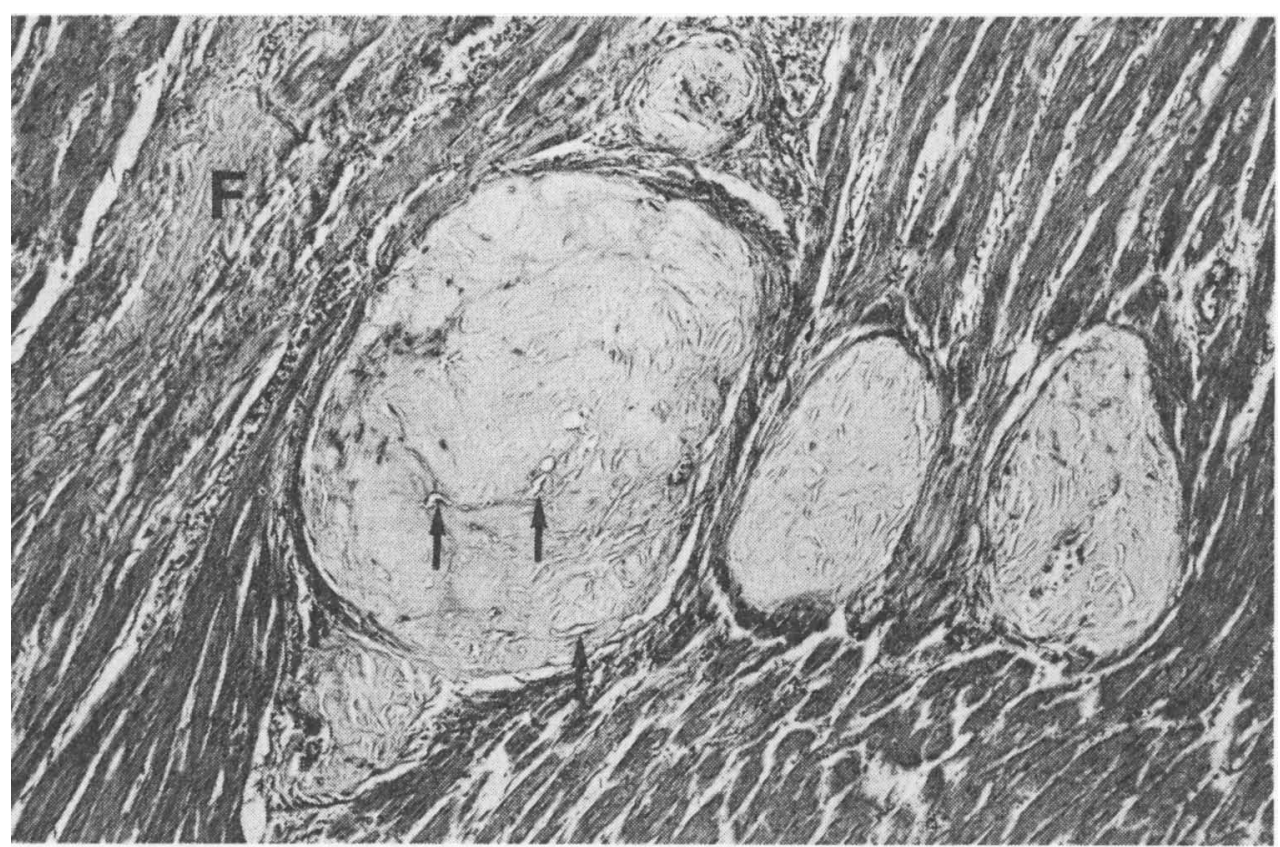

F i g u r e 4. Intramural arterioles almost totally occluded by amyloid. Some endothelial-lined small clefts in the amyloid (arrows) are observed. Focal myocardial fibrosis is indicated (F). Goldner's trichrome. $\times 140$.

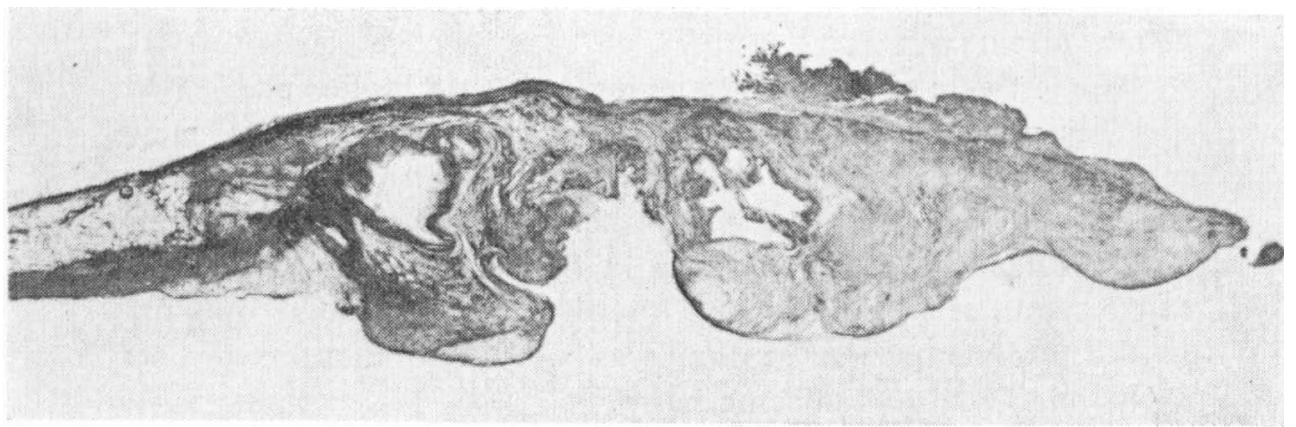

Figure 5. Section from the anterior mitral valve of a 14 years old dog. Amyloid is observed at the line of closure and as atrial thickening in the proximal portion of the valve. Verhoeff. $\times 14$. 


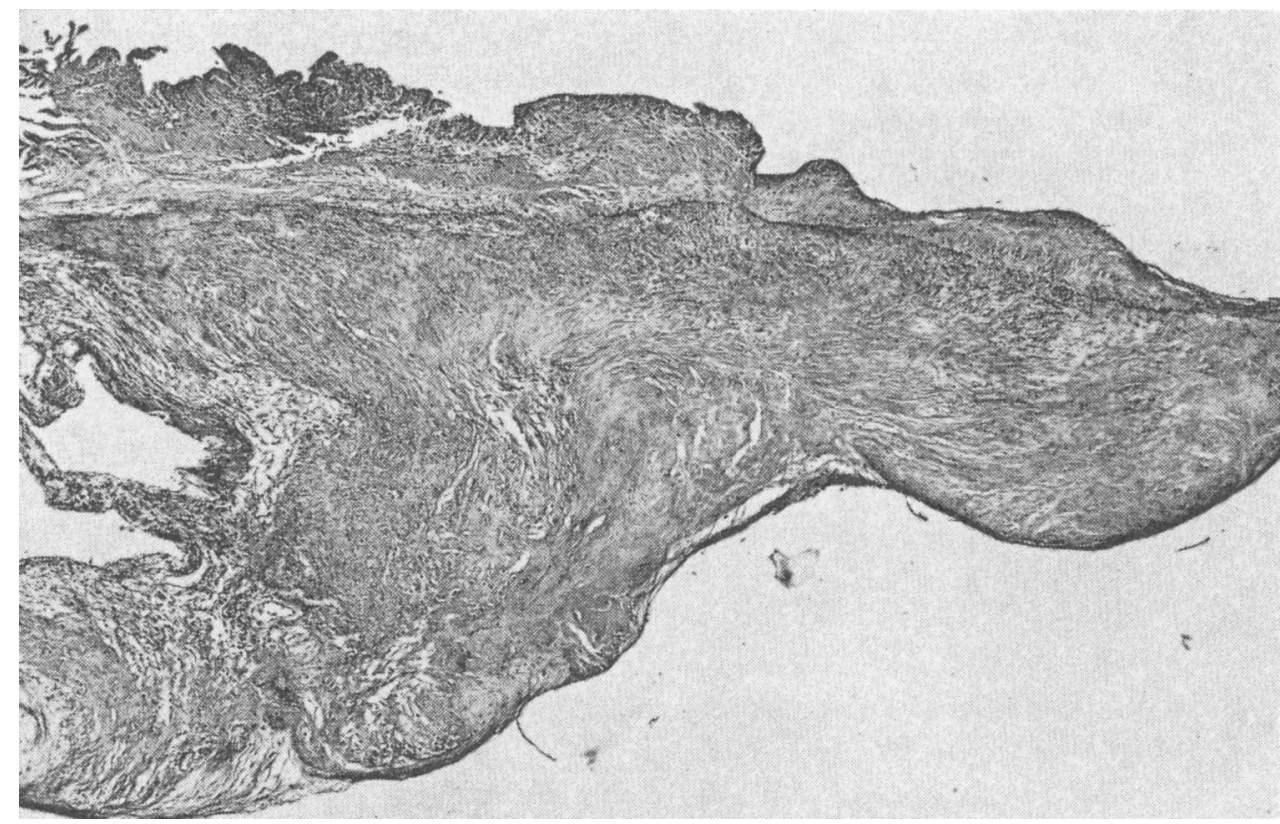

F ig u re 6. Higher power of section depicted in Fig. 5. There are amyloid deposits traversed by fibrous tissue in the atrialis and the fibrosa. The elastic lamina is fragmented. Verhoeff. $\times 33$.

ings (Fig. 6). Amyloid was also often observed in the lamina fibrosa. In both atrialis and fibrosa the amyloid was traversed by streaks of fibrous tissue. In the spongiosa there was fibrosis with irregular elastic fibrils, but seldom amyloid deposits. In the most severely affected valves the normal laminal structure was totally disorganized.

The left side of the heart was involved in a higher proportion of cases with cardiac amyloidosis than the right (Table 1). In moderately and severely affected cases amyloid was observed in the vessels of both ventricular walls. In slightly affected hearts amyloid deposits were only seen in the left ventricle, especially in the papillary muscles. The distribution of vascular amyloid in the interventricular septum was similar to that in the left ventricular wall of the same heart.

The amyloid deposits both in the vessels and the valves stained as a homogenous intercellular eosinophilic substance with haematoxylin and eosin and showed a positive PAS-reaction. 
T a b l e 1. Distribution and degree of amyloid deposits in the hearts.

\begin{tabular}{lcccc}
\hline \multirow{2}{*}{ Location } & $\begin{array}{c}\text { Number } \\
\text { of cases }\end{array}$ & \multicolumn{3}{c}{ Degree of cardiac amyloidosis } \\
\cline { 3 - 6 } & & slight & moderate & severe \\
\hline left ventricular wall & 32 & 7 & 6 & 19 \\
interventricular septum & 24 & 0 & 7 & 17 \\
right ventricular wall & 19 & 0 & 8 & 11 \\
left atrium & 3 & 3 & 0 & 0 \\
right atrium & 3 & 3 & 0 & 0 \\
mitral valves & 6 & 0 & 2 & 4 \\
tricuspid valves & 2 & 1 & 1 & 0 \\
aortic cusps & 3 & 1 & 2 & 0 \\
\hline
\end{tabular}

It stained positively with alkaline Congo red, although the intensity of staining varied considerably. There was a rather strong yellow fluorescence after staining with thioflavine $T$ (Figs. 2 and 3 ). The amyloidosis gave a very weak or no metachromasia with crystal or methyl violet. Polarized light was a useful diagnostic method, as amyloid is birefringent in this light. Congo red staining allowed amyloid in a particular section to be demonstrated by conventional, polarization, and ultraviolet microscopy.

Routine sections of the other organs were searched for amyloid. Slight deposits were found in the small arteries of other organs (liver, kidney, spleen, intestine and brain) only in the cases of severely affected hearts.

\section{DISCUSSION}

Although amyloidosis was first described over one hundred years ago (Virchow 1857) the aetiology is still obscure. The subdivision of amyloidosis suggested by Lubarsch (1929) in a typical or secondary form and in an atypical or primary form is still used. The primary form is also called paramyloidosis (Picchini \& Fabris 1930). The typical amyloidosis requires a predisposing disease while the atypical form is not preceded by a primary disease. On this basis, senile cardiac amyloidosis falls into the category of primary amyloidosis (Symmers 1956).

In all 32 cases of cardiac amyloidosis in the present investigation, amyloid deposits were observed in the intramural coronary arterial and arteriolar branches. However, deposits were observed in the main subepicardial arteries in only three cases. 
Interstitial myocardial amyloid was slight and only found in four cases with severe vascular amyloidosis. This distribution of amyloid in the vessels but seldom in the interstitial tissue is in agreement with the studies by Matthias \& Jakob (1969). These authors studied 14 dogs with cardiac amyloidosis but never observed amyloid in the myocardial interstitium. In the aged human heart, on the other hand, diffuse fibrillar interstitial amyloidosis is frequently encountered. Predilection sites are the auricles and the atria (Schwartz 1965; 1967; Pomerance 1965; 1966). In his comparative studies of man and dogs Schwartz (1970) found the above-mentioned difference in the distribution of amyloid. He supposed that the interstitial type of amyloidosis would be much more common in the canine material, if the auricles and the atria had been examined. The present study, which also comprised the atria, showed that the interstitial cardiac amyloidosis in the dog is unusual, and when it does occur, it is only slight. The intramural coronary arterial and arteriolar amyloid deposits are, however, often severe and obturate the lumen with myocardial necroses and fibroses as result.

In the present investigation amyloidosis in the intramural coronary arteries and the valves was found to be more common in old dogs than in middle-aged dogs. In a necropsy series of 100 dogs Dahme \& Reif (1964) found 11 cases of coronary arterial amyloidosis among 42 animals over 10 years of age. Schanz (1965) observed seven cases in a study of 120 dogs. Matthias \& Jakob found that $29 \%$ of 14 dogs over 10 years of age were affected with senile coronary arterial amyloidosis. The relatively small number of dogs in these studies might be the reason why the frequency of senile amyloidosis was higher than in the present investigation.

Valvular amyloidosis was demonstrated in six cases. This localization of senile cardiac amyloid was reported in man by several authors, but only a few cases are reported in animals. Angrist (1964) and Detweiler et al. (1968) mention that valvular amyloidosis is sometimes seen in old dogs. In two other works (Matthias \& Jakob; Schwartz 1970) valvular amyloidosis was demonstrated. Schneider et al. (1971) presented a study of five dogs with valvular amyloidosis. Only old dogs were affected, and the distribution in the valves was in agreement with the present study.

The aetiology of senile cardiac amyloidosis is still a matter 
of dispute. Possible factors concerned with cardiac amyloidosis in man have been considered in some communications. Malnutrition and malignant disease were suggested by Mulligan (1958) and Eliot et al. (1961). However, Buerger \& Braunstein (1960) and Pomerance (1966) found nothing to confirm these views.

The most widely accepted view on the pathogenesis of amyloidosis holds that it is a result of immunological disturbances. Aging is considered to be an autoimmune process (Comfort 1963). Comfort therefore suggested that the senile cardiac amyloidosis is an aging process. The only common factors in the present cases were advanced age of the animals and the distribution of amyloid deposits. Cohen et al. (1965) showed that amyloid fibrils are formed on the surface of reticulo-endothelial cells. However, it is not clear how such fibrils enter the vessel wall or in what way they contribute to amyloid deposits therein. According to Kennedy (1966) amyloid deposition in blood vessels may result from transvascular filtration of an abnormal plasma protein which is formed by plasma cells. This protein is then conjugated with acid mucopolysaccharides in the vessel wall. This theory is supported by the histochemical studies of coronary arterial amyloidosis in the dog (Jönsson 1972). Tryptophan, tyrosine, cystine/cysteine, triglycerides, phosphoglyceride phospholipids and cholesterol esters were observed in the amyloid. These amino acids and lipids are normal constituents of the plasma proteins.

A genetic basis for senile amyloidosis has been suggested for man (Gafni et al. 1964) and mice (Thung 1957). Thung was of the opinion that experimentally induced amyloidosis in mice was a precocious form of the genetically determined spontaneous senile amyloidosis. If senile amyloidosis in the dog, too, is a genetically determined disorder, it would be logical to assume that in breeds with this trait amyloidosis will develop spontaneously as the senile form in old dogs. In younger dogs it may be manifested as other forms of primary amyloidosis or as typical secondary amyloidosis in response to a wide variety of accelerating factors. Perhaps the process in dogs is accelerated by malnutrition, a condition which in mice is known to play a part in the development of amyloidosis. 


\section{REFERENCES}

Angrist, A.: Aging heart valves and a unitary pathological hypothesis for sclerosis. J. Geront. 1964, 19, 135-143.

Buerger, L. \& H. Braunstein: Senile cardiac amyloidosis. Amer. J. Med. $1960,28,357-367$.

Cohen, A. S., E. Gross \& T. Shirahama: The light and electron autoradiographic demonstration of local amyloid formation in spleen explants. Amer. J. Path. 1965, 47, 1079-1111.

Comfort, A.: Mutation, autoimmunity and ageing. Lancet 1963, 2, $138-141$.

Dahme, E. \& E. Reif: Weitere Untersuchungen zur Pathomorphologie des Kranzarteriensystems beim Hund. (Further studies on the pathology of the coronary arterial system in the dog). Berl. Münch. tierärztl. Wschr. 1964, 77, 181-185.

Detweiler, D. K., H. Luginbühl, J. W. Buchanan \& D. F. Patterson: The natural history of acquired cardiac disability of the dog. Ann. N.Y. Acad. Sci. 1968, 147, 318-329.

Eliot, R. S., H. J. Mc Gee \& S. G. Blount: Cardiac amyloidosis. Circulation $1961,23,613-622$.

Gafni, J., E. Sohar \& H. Heller: The inherited amyloidoses. Their clinical and theoretical significance. Lancet 1964, 1, 71-74.

Hjärre, A. \& I. Nordlund: Om atypisk amyloidos hos djuren. (On atypical amyloidosis in animals). Skand. Vet.-Tidskr. 1942, 32, $385-441$.

$J a k o b, W .:$ Untersuchungen über die Amyloidose der Karnivoren unter besonderer Berücksichtigung der Altersamyloidose. (Studies on canine amyloidosis with special attention to senile amyloidosis). Zbl. Vet.-Med., Reihe A, 197.0, 17, 818-829.

Jönsson, L.: Coronary arterial lesions and myocardial infarcts in the dog. A pathologic and microangiographic study. Acta vet. scand. 1972, Suppl. 38.

Kennedy, J. S.: Sulphur-35 in experimental amyloidosis. Lab. Invest. 1966, 15, 84-95.

Lubarsch, O.: Zur Kentniss ungewöhnlichen Amyloidablagerungen. (For the knowledge of unusual amyloid deposits). Virchows Arch. path. Anat. 1929, 271, 867-889.

Matthias, D. \& W. Jakob: Untersuchungen über die Altersamyloidose des Hundes und ihre Stellung zur sog. typischen Amyloidose. (Studies on senile canine amyloidosis in relation to typical amyloidosis). Zbl. Vet.-Med. 1969, 16, 477-494.

Mulligan, R. M.: Amyloidosis of the heart. Arch. Path. 1958, 65, 615630.

Picchini, L. \& A. Fabris: Sulle paramyloidosi. (On paramyloidosis). Arch. Sci. med. 1930, 54, 551-569.

Pomerance, A.: Senile cardiac amyloidosis. Brit. Heart J. 1965, 27, 711-718.

Pomerance, A.: The pathology of senile cardiac amyloidosis. J. Path. Bact. 1966, 91, 357-367. 
Puchtler, H., F. Sweat \& M. Levine: On the binding of Congo red by amyloid. J. Histochem. Cytochem. 1962, 10, 355-364.

Schanz, U.: Beiträge zur Frage kausaler Zusammenhänge zwischen Angiopathien und anderen Erkrankungen bei Hunden anhand histologischen Untersuchungen der intramuralen Herzgefässe. (Contributions to the question of causes between angiopathy and other diseases in dogs concerning histological studies on the intramural cardiac vessels). Thesis. Giessen 1965.

Schneider, P., E. Ernst \& G. Trautwein: Amyloidose der Herzklappen beim Hund. (Amyloidosis in cardiac valves in dogs). Vet. Path. (Basel) 1971, 8, 130-145.

Schwartz, P.: Uber Amyloidose des Gehirns, der Langerhansschen Inseln und des Herzens alter Personen. (Amyloidosis of the brain, the Langerhans' islands and the hearts of aging people). Zbl. allg. Path. path. Anat. 1965, 108, 169-187.

Schwartz, P.: Uber Kardiovaskuläre Amyloiddegeneration im Alter. (Cardiovascular amyloid degeneration in aging people). $\mathrm{Zbl}$. allg. Path. path. Anat. 1967, 110, 341-350.

Schwartz, P.: Amyloidosis. Cause and Manifestation of Senile Deterioration. Charles C. Thomas, ed., Springfield, Ill. 1970.

Symmers, W. St. C.: Primary amyloidosis: A review. J. clin. Path. 1956, 9, 187-211.

Thung, $P$. J.: The relation between amyloid and ageing in comparative pathology. Gerontologia (Basel) 1957, 1, 234-254.

Trautwein, G.: Vergleichende Untersuchungen über das Amyloid und Paramyloid verschiedener Tierarten. I. Histomorphologie und färberische Eigenschaften des Amyloids und Paramyloids. (Comparative studies on the amyloid and paramyloid in different species of animals. I. Histological and histochemical qualities of the amyloid and paramyloid). Path. Vet. (Basel) 1965 a, 2, 297-327.

Trautwein, G.: Vergleichende Untersuchungen über das Amyloid und Paramyloid verschiedener Tierarten. II. Histochemie des Amyloids und Paramyloids. (Comparative studies on the amyloid and paramyloid in different species of animals. II. Histochemistry of the amyloid and paramyloid). Path. Vet. (Basel) $1965 \mathrm{~b}$, $2,493-513$.

Vassar, P. S. \& C. F. A. Culling: Fluorescent stains, with special reference to amyloid and connective tissues. Arch. Path. 1959, 68, $487-498$.

Virchow, R.: Neue Beobachtungen über Amyloide Degeneration. (New observations of the amyloid degeneration). Virchows Arch. path. Anat. 1857, 11, 188-189.

\section{SAMMANFATTNING}

Amyloidos $i$ hjärtat hos hund.

Av 594 obducerade hundar påvisades 32 fall av senil hjärtamyloidos. Åldern varierade mellan 10 och 16 år. Amyloid påvisades $i$ intramurala artärer och arterioler, huvudsakligen i kammarmuskulaturen. 
Kärlen var ofta obturerade av amyloid. Nekroser och fibroser i hjärtmuskulaturen var vanliga komplikationer till kärlskadorna. I tre fall påvisades amyloid även i de stora extramurala kransartärerna. I motsats till förhållandet hos människa sågs sällan interstitiell amyloid degeneration. I endast fyra fall förekom lindriga amyloiddepositioner av denna typ. Amyloid i mitralisklaffar, tricuspidalisklaffar och aortaklaffar förekom i sex, två respektive tre fall. Undersökningen har visat att primär hjärtamyloidos endast förekommer hos gamla hundar, och att förändringarna huvudsakligen är lokaliserade till hjärtats intramurala artärer och arterioler.

(Received December 3, 1973).

Reprints may be requested from: L. Jönsson, Department of Pathology, Royal Veterinary College, S-104 05 Stockholm 50, Sweden. 